https://doi.org/10.31470/2706-7904-2020-15-59-62

\title{
PSYCHOLINGUISTIC ISSUES OF TRANSLATION, ADAPTATION AND VALIDATION OF «THE BIG THREE PERFECTIONISM SCALE»
}

\section{Психолінгвістичні проблеми перекладу, адаптації та валідизації методики "велика тривимірна шкала перфекціонізму»}

\author{
Tamara Grubi \\ Ph.D. in Psychology, Associate Professor \\ Borys Grinchenko University of Kyiv (Ukraine) \\ t.grubi@kubg.edu.ua \\ https://orcid.org/0000-0002-2345-588X
}

\begin{abstract}
Increased interest in the study of perfectionism of a person is becoming more and more relevant, it can be explained by the rapid pace of life, increasing competition, the cult of perfectionism and individual accomplishments. To diagnose perfectionism they use questionnaires, however, the vast majority of them have two scales. In the «Great Triennial Scale of Perfectionism», perfectionism is viewed as a richly varied construct that combines three types - «hard», «self-critical» and «narcissistic». In turn, each of these types is composed of several scales, which are included in the inventory in order to increase reliability and accuracy in the assessment. The results of the process of translation, adaptation and standardization of the quantifier are presented. Data on primary statistical data processing, reliability, validity of the technique, correlation and factor analysis of its indicators according to psychometric requirements are given. The reliability and validity of the instrument and the possibility to use it for investigative and psychodiagnostic purposes has been proved.
\end{abstract}

Key words: perfectionism, objectification, adaptation, validization, translation.

\section{Introduction}

In the scientific literature there is a growing interest of foreign and Ukrainian researchers to the problem of perfectionism. This increased interest to the research of perfectionism can be explained by different factors: the fast pace of life, high level of competition and the growing level of requirements to employee; the cult of excellence and individual achievements which is broadcasted by the media. These and other factors determine the need of self-development, improvement in professional and personal spheres. Different questionnaires are used for identifying type of perfectionism. The analysis of the 
Ukrainian literature shows that there are near twenty questionnaires that measure just the type of perfectionism.

The purpose of our investigation is to translate, adapt and validate the Englishlanguage questionnaire «The Big Three Perfectionism Scale» (Smith, 2016).

\section{Methods and Techniques of the Research}

The process of translation, adaptation and validation of the questionnaire was carried out in three stages.

At the first stage - translation of instructions, items and descriptions of scales for respondents from English to Ukrainian. A symmetrical type of translation is used, which preserves the meaning of the original and provides a suitable understanding of the text. The main attention was paid to maintaining the psychological content of the items. Three independent interpreters analyzed different versions of translation options. To avoid differences in the perception of text, the reverse translation of items was made by a foreign philologist, who was not acquainted with the English version of the questionnaire. An independent expert compared the text of the original and the translated version of the questionnaire and confirmed its authenticity. After comparing the result of the reverse translation with the text of the original, some changes and modifications were added into the Ukrainian version.

The second stage involved an expert substantive assessment of the psychological relevance of translation and understanding by respondents. A group of experts $(n=12)$ analyzed each item to ensure an acceptable understanding of the questionnaire. The experts were acquainted with a translation version that is as close as possible to the original English-version text. The obtained data were subjected to semantic and lexical analysis of understanding of items. The translation of the items revealed a certain inadmissibility of some statements in the conditions of Ukrainian culture and therefore there were a changes.

The third, standardization, stage involved the following tasks: a correlation analysis between the items of the questionnaire in the English language version and Ukrainian translation, assessing the internal reliability of items (Cronbach's Alpha) and investigating the concept validity of the translated version of the questionnaire, collection of relevant standards for the Ukrainian sample.

In the original, English version, the approbation of the questionnaire was conducted on a sample of 367 community adults (Smith, 2016).

The subject of our investigation «Psychology of perfectionism of scientific and pedagogical staff of higher education» the adaptation and validation of the questionnaire was conducted on a sample of 350 lectures and professors from different regions of 
Ukraine. Statistical processing of the obtained data in accordance with psychometric requirements was performed (Akimova, 2005).

For processing of the data and evaluating its reliability, different methods were used: initial statistical data, reliability tests, methods of validity, correlation and factor analysis. The computer program SPSS (version 21.0) and Windows 10 was used for statistical processing of the received data.

\section{Results}

The questionnaire contains 45 items with instructions to respond to each item using a 5point rating scale from 1 (strongly disagree) to 5 (strongly agree). The questionnaire is seen as assesses three higher-order global factors (rigid perfectionism, self-critical perfectionism, narcissistic perfectionism) via 10 lower-order perfectionism scales (Smith, 2016).

Thru the factor analysis, 44 items from 45 had a large factor weight and sufficient conceptual interdependence with the facets. However, the first item of the questionnaire «I have a strong need to be perfect» had a small factor weight (0.245), and the correlation of the item with the total score was only 0.015 . Therefore, this item was removed and the final version of the questionnaire consists of 44 items. Thus, the factor analysis revealed the consistency of the questionnaire items when changing the language and mentality of the respondents.

Standardizing the questionnaire, we determined the arithmetic mean and standard deviations of the indicators (Table 1). These indicators were calculated according to the generally accepted procedure (Burlachuk, 2003).

During normalization we used interval 1 sigma for the average level and 0.5-1 sigma for all other levels (Table 1). Since each scale has a different number of items for the possibility of comparing the results on different scales, we find the total score for the specified numbers of items.

Table 1. Average values on the scales of the questionnaire $(n=350)$

\begin{tabular}{|c|c|c|c|c|}
\hline $\begin{array}{c}\text { Global factors, scales of } \\
\text { perfectionism }\end{array}$ & & $\begin{array}{c}\text { Standard } \\
\text { Meandeviation }\end{array}$ & Minimum & Maximum \\
\hline Rigid perfectionism & 3.63 & 0.69 & 3.19 & 3.87 \\
\hline - Self-oriented perfectionism & 3.68 & 0.71 & 3.29 & 3.98 \\
\hline - Self-worth contingencies & 3.58 & 0.84 & 3.02 & 3.87 \\
\hline - Self-critical perfectionism & 2.88 & 0.63 & 2.46 & 3.09 \\
\hline - Concern over mistakes & 3.02 & 0.9 & 2.43 & 3.33 \\
\hline - Doubts about actions & 2.37 & 0.83 & 1.86 & 2.68 \\
\hline
\end{tabular}


Psycholinguistics in a Modern World - 2020. Proceedings of the 15th International Scientific and Practical Conference (Pereiaslav-Khmelnytskyi, 22-23 October, 2020)

\begin{tabular}{|c|c|c|c|c|}
\hline$\bullet$ Self-criticism & 3.37 & 0.8 & 2.89 & 3.69 \\
\hline$\bullet$ Socially prescribed perfectionism & 2.86 & 0.76 & 1.99 & 3.16 \\
\hline Narcissistic perfectionism & 2.63 & 0.67 & 2.25 & 2.88 \\
\hline$\bullet$ Other-oriented perfectionism & 2.94 & 0.85 & 2.45 & 3.27 \\
\hline$\bullet$ Hypercriticism & 2.68 & 0.76 & 2.27 & 2.99 \\
\hline$\bullet$ Grandiosity & 2.27 & 0.86 & 1.80 & 2.61 \\
\hline$\bullet$ Entitlement & 2.6 & 0.83 & 2.10 & 2.92 \\
\hline General level of perfectionism & 3.04 & 0.51 & 2.59 & 3.07 \\
\hline
\end{tabular}

Validating the questionnaire, data on the reliability of the scales were obtained, namely: reliability, splitting the questionnaire in half and the internal consistency of Cronbach $(\alpha)$ and established the appropriate standards. For testing the internal consistency of each scale, the $\alpha$-Cronbach's coefficient was calculated. All $\alpha$ indicators can be considered acceptable in terms of requirements for psychological diagnostic tools. The total reliability factor $(\alpha)$ for the questionnaire is 0.912 .

The correlation coefficient of the questionnaire - split-half coefficient (Guttman Split-half) is equal to 0.650 . The indicator $\alpha$ (alpha) for the first part of the questionnaire is 0.863 , for the second part -0.893 .

These values satisfy psychometric requirements for effective psychological diagnostic tools (Akimova, 2005). The intercorrelation matrix of the questionnaire indicates the internal consistency of the scales and the sufficient contribution of each scale to the overall logic of the investigation of perfectionism.

\section{Conclusions}

The standardization procedure of the questionnaire on the Ukrainian sample satisfies the requirements for psychological diagnostic tools. Certainly, its standardization is not fully completed, as this process should continue with a certain frequency, on a slightly larger and more diverse sample, in particular, by other scientists in the education system.

\section{References}

Акимова, М.К. (2005). Психологическая диагностика. Санкт-Петербург: Питер.

Бурлачук Л.Ф. (2003). Психодиагностика. Санкт-Петербург: Питер.

Smith, M.M., Saklofske, D.H., Stoeber, J., \& Sherry, S.B. (2016). The big three perfectionism scale: A new measure of perfectionism. Journal of Psychoeducational Assessment, 34(7). http://dx.doi.org/10.13072/midss.5392 